\title{
Optimum Support Design for Openings Considering Intact Rockmass in Production Level of Maddhapara, Granite Mine, Maddhapara, Dinajpur, Bangladesh
}

\author{
Chowdhury Quamruzzaman ${ }^{1}$, Mohammad Tofayal Ahmed ${ }^{2}$, Badrul Alam ${ }^{3} \&$ \\ A.K.M Fayazul kabir ${ }^{4}$ \\ ${ }^{1,4}$ (Department of Geology, University of Dhaka, Bangladesh) \\ ${ }_{2}^{2}$ (Department of Petroleum and Mining Engineering, University of Jessore Science and Technology, \\ Bangladesh) \\ ${ }^{3}$ (Department of Mining, Institute of Mining, Mineralogy \& Metallurgy, BCSIR,Bangladesh)
}

\begin{abstract}
Maddhapara Granite mine is the only Hardrock underground mine, which is contributing to infrastructure development of Bangladesh. It was established in 1995 by the North Korean contractor (NAMNAM).Over the past few years it was observed that in some of the vital area of the pit bottom, appears to be vulnerable, where needs to be taken special consideration to make sure the safe working environment for the miners and equipment machinery as well. The authors of this research have taken an attempt to identify and overcome such problem by a research program. In this research, our outcome has been established that the, optimum support have to be determined by using Rock Support Interaction Analysis for rock mass in production level. During design stage, it was considered that the total rock mass is intact (based on initial geological survey data), means there are no wedges along the opening. However a little amount of geological abnormality anticipated in the production level during construction phase. Due respect to that, our research recommended that, there has to be a little amount of support is needed for any kinds of openings in first category of rock, in second category it has to be considered by shotcreting of different thickness of lining in roof and the sidewall. In third category of rock, support system has to be considered by rock bolting and latter shotcrete the roof and side wall. Finally 2.3, 4.6 and $10.73 \mathrm{~m}$ openings in third category of rock there needs to be $0.0095 \mathrm{~m} 0.015 \mathrm{~m}$ and $0.026 \mathrm{~m}$ fiber reinforced shotcrete and $3 \mathrm{~m}$ bolt length and blot spacing with 1.5, 1, $0.95 \mathrm{~m}$ respectively in roof and inside wall $0.006 \mathrm{~m}, 0.015$ and $0.045 \mathrm{~m}$ shotcrete lining have to be considered for safe mining work.
\end{abstract}

Keywords: Support equation, Data analysis, Intact rock mass, Broken rock mass, Uniaxial compressive strength.

\section{INTRODUCTION}

Maddhapara Granite Mining Company (MGMC) which is the first experience of underground hard rock mining and second major mining project in Bangladesh. The MGMC lies between latitude $25^{\circ} 23^{\prime} 43^{\prime \prime}$ and $25^{\circ} 34^{\prime} 43^{\prime \prime} \mathrm{N}$ and longitude $89^{\circ} 03^{\prime} 34^{\prime \prime} \mathrm{E}$ and $89^{\circ} 05^{\prime} 04^{\prime \prime} \mathrm{E}$. It is about $23 \mathrm{kms}$ north east of Phulbari Railway station. The Bangladesh map and location map of the study area is in figure 1 and Figure: 2, the map of the production level is shown in figure: 3.The principle objective is to design the minimum underground support to make the tunnel stable resisting from further deformation. In order to design the support of production level the sequences of calculations of Rock Support Interaction Analysis and support equations of Hoek and Brown's 1982 have been followed. And at last the suitable supports for particular openings with in the production Level have been determined.

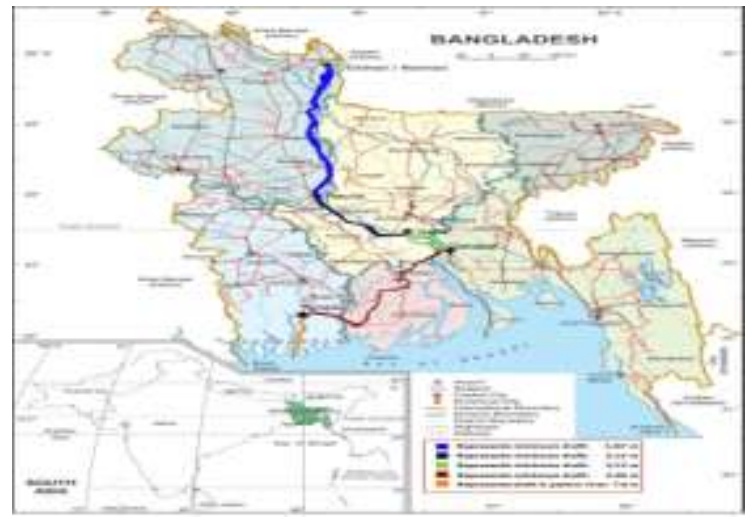

Figure: 1, Map of Bangladesh 


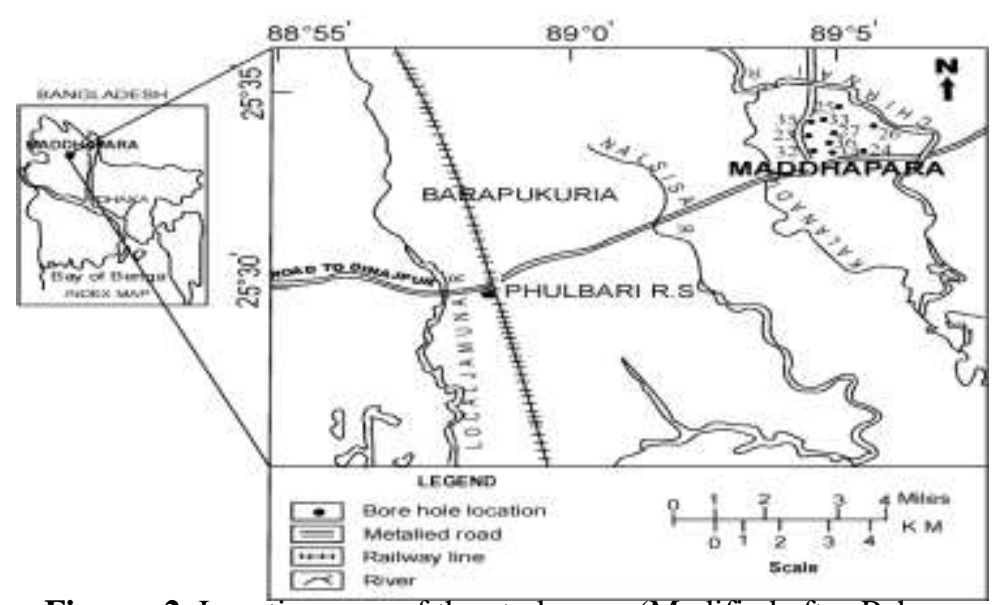

Figure: 2, Location map of the study area (Modified after Rahman, 1987)

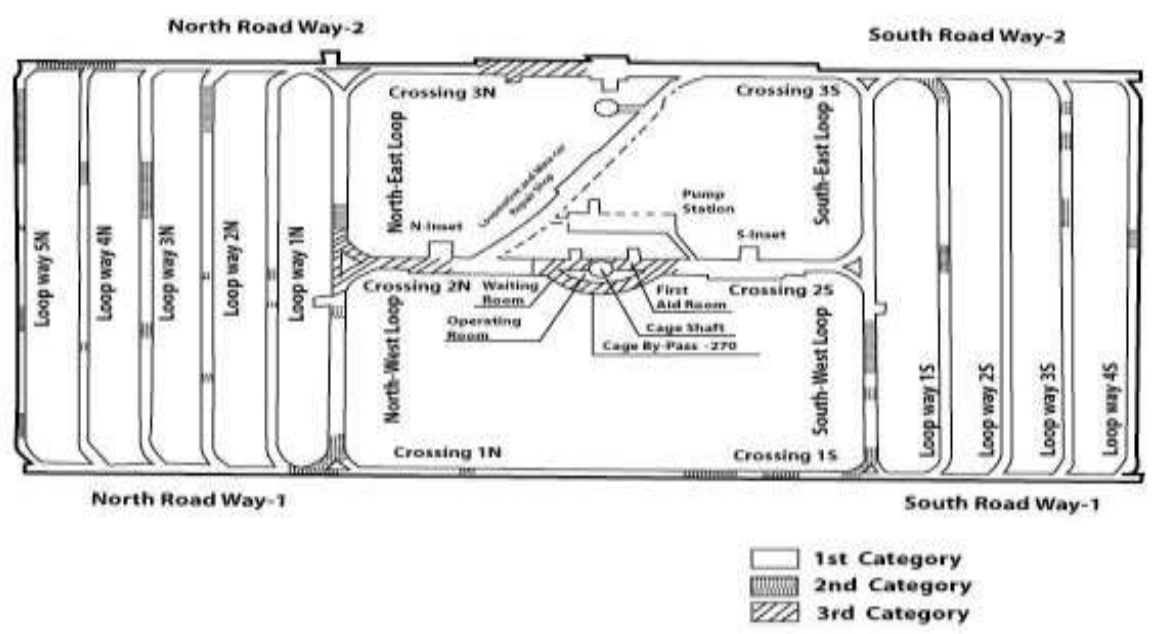

Figure: 3, Production Level of Maddhapara Granite Mine, Bangladesh (MHMC)

\section{METHODOLOGY}

In order to use Rock Support Interaction Analysis for support design the following steps have been followed:

1. Firstly the load deformation curves of different categories of rock have been generated considering the tunnel deformation and support pressure values.

2. Secondly the support stiffness and maximum support pressure have been calculated by using the equations of Hoek and Brown 1982. In the graph where support pressure and support stiffness of particular support system have satisfied the load deformation curves then the support has been considered for support estimation.

A program (Appendix-A) has been generated by following the sequence of calculation of Rock Support Interaction Analysis (Hoek and Brown, 1982). The values of support pressure and tunnel deformation have been determined by using this program. In case of preparing load deformation curves of different categories of rock the minimum value of load deformation has been taken to zero.

In selection of support system, the interactive nature of the load deformation characteristics of both rock mass and support system have been considered as proposed by Hoek and Brown 1982.

\section{SUPPORT EQUATIONS}

To have the support reaction the following equations of Hoek and Brown 1982 have been used.

For Shotcrete :

Support stiffness and maximum support pressure have calculated by using the following equations (Hoek \& Brown, 1982)

$$
\begin{gathered}
K_{c}=\frac{E_{c}\left(r_{i}^{2}-\left(r_{i}-t_{c}\right)^{2}\right)}{\left(1+\delta_{c}\right)\left[\left(1-2 \delta_{c}\right) r_{i}^{2}+\left(r_{i}-t_{c}\right)^{2}\right]} \\
P_{\text {sc } \max }=\frac{1}{2} \sigma_{\text {c.conc. }}\left[1-\frac{\left(r_{i}-t_{c}\right)^{2}}{r_{i}{ }^{2}}\right]
\end{gathered}
$$


Here,

$\mathrm{E}_{\mathrm{c}}=$ modulus of elasticity

$\gamma_{\mathrm{c}}=$ Possions ratio

$\mathrm{t}_{\mathrm{c}}=$ thickness of lining

$\mathrm{r}_{\mathrm{i}}=$ tunnel radius

$\sigma_{\text {c.conc. }}=$ Uniaxial compressive strength

For Rock bolts:

Support stiffness and maximum support pressure for rock bolt have been calculated by using the following equations (Hoek \& Brown, 1982)-

$$
\begin{aligned}
& \frac{1}{K_{b}}=\frac{S_{c} S_{l}}{r_{i}}\left[\frac{4 Z}{\pi d_{b} E_{b}}+Q\right] \\
& P_{s b \max }=\frac{T_{b f}}{S_{c} S_{l}}
\end{aligned}
$$

Here,

$1=$ bolt length

$\mathrm{d}_{\mathrm{b}}=$ bolt diameter

$\mathrm{E}_{\mathrm{b}}=$ elastic modulus

$\mathrm{Q}=$ load deformation constant

$\mathrm{T}_{\mathrm{bf}}=$ Ultimate failure load

$\mathrm{r}_{\mathrm{i}}=$ tunnel radius

$\mathrm{S}_{\mathrm{c}}=$ Circumferancial bolt spacing

$\mathrm{S}_{\mathrm{l}}=$ Longitudinal bolt spacing

Combined support Calculation Sequence:

To use the combined support of shotctete and rock bolt, the following sequences of combined support of Hoek \& Brown, 1982 have been followed.

(a) $\mathrm{U}_{\max 1}=\mathrm{r}_{\mathrm{i}} \cdot \mathrm{P}_{\mathrm{amax}} / \mathrm{K}_{1}$

(b) $\mathrm{U}_{\max 2}=\mathrm{r}_{\mathrm{i}} \cdot \mathrm{P}_{\mathrm{amax} 2} / \mathrm{K}_{2}$

(c) $\mathrm{U}_{12}=\mathrm{r}_{\mathrm{i}} \cdot \mathrm{Pi} /\left(\mathrm{K}_{1+} \mathrm{K}_{2}\right)$

(d)For $\mathrm{U}_{12}<\mathrm{U}_{\max 1}<\mathrm{U}_{\max 2}$

$$
\frac{U_{i}}{r_{i}}=\frac{U_{i o}}{r_{i}}+\frac{P_{i}}{\left(K_{1}+K_{2}\right)}
$$

(e)For $\mathrm{U}_{12}>\mathrm{U}_{\max 1}<\mathrm{U}_{\max 2}$

$$
P_{\max 12}=U_{\max 2}\left(K_{1}+K_{2}\right) / r_{i}
$$

(f)For $\mathrm{U}_{12}>\mathrm{U}_{\max 2}<\mathrm{U}_{\max 1}$

$$
P_{\max 12}=U_{\max 1}\left(K_{1}+K_{2}\right) / r_{i}
$$

Here,

$\mathrm{K}_{1}=$ Suppot stiffness for system 1

$\mathrm{P}_{\text {smaxl }}=$ maximum support pressure for system 1

$\mathrm{K}_{2}=$ Suppot stiffness for system 2

$\mathrm{P}_{\mathrm{smax} 2}=$ maximum support pressure for system 2

$\mathrm{U}_{\mathrm{io}}=$ Initial tunnel deformation before installation of support

\section{DATA ANALYSIS}

For Rock support Interaction Analysis certain types of data have been used to generate the load deformation curves.

Material Constants:

Material constants for intact rock and for broken rock mass have been used for Rock Support Interaction Analysis. These are given as follows-

For Intact Rock Mass:

The material constant value for different categories of rock with respect to rockmass rating determined by Badrul, 2006 (CSIR and NGI classification) have been estimated by using of Hoek and Brown 1982. 


\begin{tabular}{|l|l|l|l|}
\hline Category & Rock mass Rating & Quality & Material Constant Value \\
\hline $1^{\text {st }}$ & CSIR-92:;NGI-24.25 & Good & $\mathrm{m}-2.5 ; \mathrm{s}-0.004$ \\
\hline $2^{\text {nd }}$ & CSIR-67;NGI-8.86 & Fair & $\mathrm{m}-0.5 ; \mathrm{s}-0.0001$ \\
\hline $3^{\text {rd }}$ & CSIR-39;NGI-5.12 & Poor & $\mathrm{m}-0.13 ; \mathrm{s}-0.00001$ \\
\hline
\end{tabular}

Table: 1. CSIR and NGI classification

For Broken Rock Mass:

Material constant for different categories of rock has been taken from "Underground Excavation in Rock, Hoek and Brown, 1982".

\begin{tabular}{|l|l|}
\hline Categories of rock & Material Constant \\
\hline $1^{\text {st }}$ & $\mathrm{m}-0.13 ; \mathrm{s}-0.00001$ \\
\hline $2^{\text {nd }}$ & $\mathrm{m}-0.025 ; \mathrm{s}-0.0$ \\
\hline $3^{\text {rd }}$ & $\mathrm{m}-0.020 ; \mathrm{s}-0.0$ \\
\hline
\end{tabular}

Table: 2. Material constant for different categories of rock

Uniaxial Compressive Strength:

Uniaxial compressive strength was carried out by Malek, (Unpublished thesis, 2003). The average data of uniaxial compressive strength for different categories of rock has been used in this analysis.

\begin{tabular}{|l|l|}
\hline Catagories & Uniaxial Compressive Strength (Mpa) \\
\hline $1^{\text {st }}$ & 116.76 \\
\hline $2^{\text {nd }}$ & 67.86 \\
\hline $3^{\text {rd }}$ & 38.27 \\
\hline
\end{tabular}

Table: 3. The average data of uniaxial compressive strength for different categories of rock

\section{Modulus of Elasticity:}

The modulus of elasticity of first category of rock has been taken from geological report of Korea South-South Cooperation Corporation (NAMNAM) 1998 and the values for other two categories of rock have been taken by using the strength ratio to the first category of rock.

\begin{tabular}{|l|l|}
\hline Category & Modulus of Elasticity(Mpa) \\
\hline $1^{\text {st }}$ & 67000 \\
\hline $2^{\text {nd }}$ & 38949.88 \\
\hline $3^{\text {rd }}$ & 21965.98 \\
\hline
\end{tabular}

Table: 4 . The strength ratio to the first category of rock.

\section{Poission's Ratio:}

The possion's ratio for different categories of rock has been taken from geotechnical report of NAMNAM, 1998.

\begin{tabular}{|l|l|}
\hline Category & Possion's ratio \\
\hline $1^{\text {st }}$ & 0.26 \\
\hline $2^{\text {nd }}$ & 0.23 \\
\hline $3^{\text {rd }}$ & 0.20 \\
\hline
\end{tabular}

Table: 5. The Possion's ratio for different categories of rock, geotechnical report of NAMNAM, 1998.

\section{Insitue Stress Magnitude:}

The Insitue stress magnitude in the production level is $7.78 \mathrm{Mpa}$ (NAMNAM, 1998).

\section{Circular Equivalent Radius:}

As the tunnel consists of vertical walls and arched roof, calculations have been made in the manner of circular equivalent from the following equation (NAMNAM, 1998) 


$$
\begin{aligned}
R_{\text {oequivalent }}=\frac{B}{2 \times K_{\text {type }}} & \\
\text { Where, } & \\
K_{\text {type }} & =\text { type coefficient according to } \frac{h}{\mathbf{B}} \\
h & =\text { height of tunnel } \\
B & =\text { Width of tunnel }
\end{aligned}
$$

\begin{tabular}{|c|c|c|c|c|}
\hline Parameters & & Value & & Value \\
\hline Modulus of Elasticity & \multirow{3}{*}{$\begin{array}{l}\frac{0}{0} \\
\frac{0}{0} \\
\frac{0}{0}\end{array}$} & 20700 & \multirow{3}{*}{ 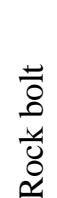 } & $207000 \mathrm{Mpa}$ \\
\hline Poission's ratio & & 0.25 & & $0.143 \mathrm{~m} / \mathrm{MN}$ \\
\hline Uniaxial Compressive strength & & $34.5 \mathrm{Mpa}$ & & $0.285 \mathrm{MN}$ \\
\hline
\end{tabular}

The circular equivalent radius of different types of openings are given as follows:

\begin{tabular}{|l|l|l|l|}
\hline Type of opening & Width $(\mathbf{m})$ & $\mathbf{K}_{\text {type }}$ & $\mathbf{R}_{\text {oequivalent }}$ \\
\hline Loop way & 2.3 & 0.83 & 1.39 \\
\hline Main way & 4.6 & 0.85 & 2.70 \\
\hline Crossing & 9.2 & 0.87 & 5.29 \\
\hline Station & 10.73 & 0.89 & 6.03 \\
\hline
\end{tabular}

Table: 6. The circular equivalent radius of different types of openings data for shotcrete and rock bolt (Hoek and Brown, 1982)

Table: 7. Data for shotcrete and rock bolt (Hoek and Brown, 1982)

In preparing the load deformation curves of different categories of rock by following the Hoek and Brown's Rock Support Interaction Analysis the minimum value of radial deformation was taken to zero as tunnel deformation can not be less than zero. Selections of support system have been taken in to account the interactive nature of load deformation characteristics of the rock mass and support system as proposed by Hoek and Brown, 1982.

\section{$1^{\text {st }}$ Category of Rock and Support System}

By using the program of rock support interaction Analysis (Appendix-A) and the data (section 2.3) different types of values (support pressure, tunnel deformation etc) have been derived. Support pressure and tunnel deformation values have been plotted. From this plots the load deformation curve of roof, sidewall and floor for all kinds of openings in first categories of rock have been generated (figure-1.3). From the graph it is clear that the deformation curves are not increasing but decreasing on and on and introduction of small amount of support in the graph creates a steep support reaction with load deformation curves of roof, sidewall and floor. So, the loop ways in $1^{\text {st }}$ category of rock would not collapse without support or very little amount of support is needed. Here the tunnel deformation $\mathbf{U}$ is limited by proximity of the tunnel face which provides a significant amount of resistance.

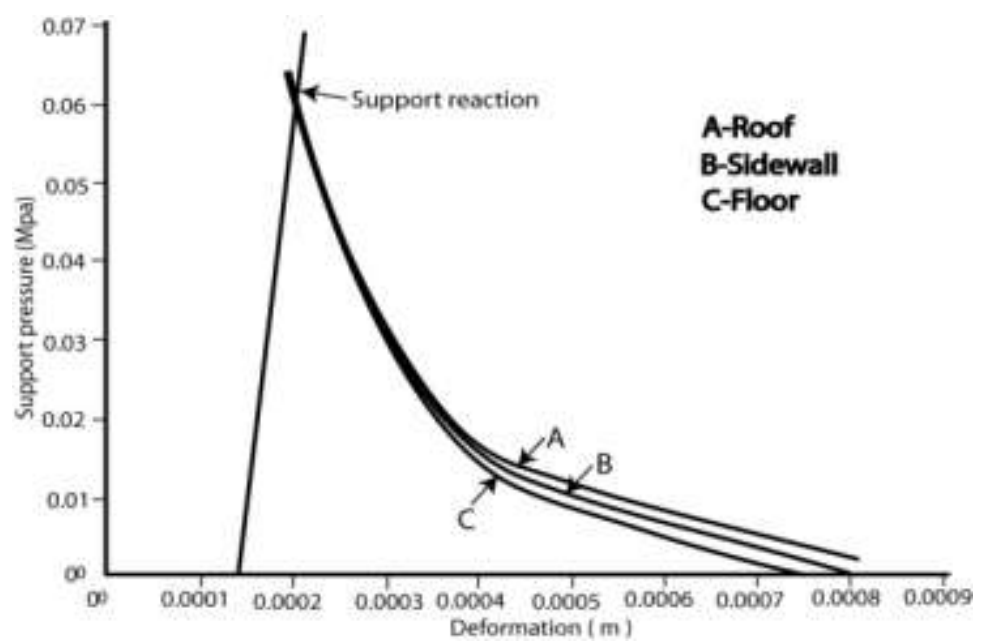

Figure 4(a): Load deformation curve and support reaction of $2.3 \mathrm{~m}$ opening in first category of rock. 


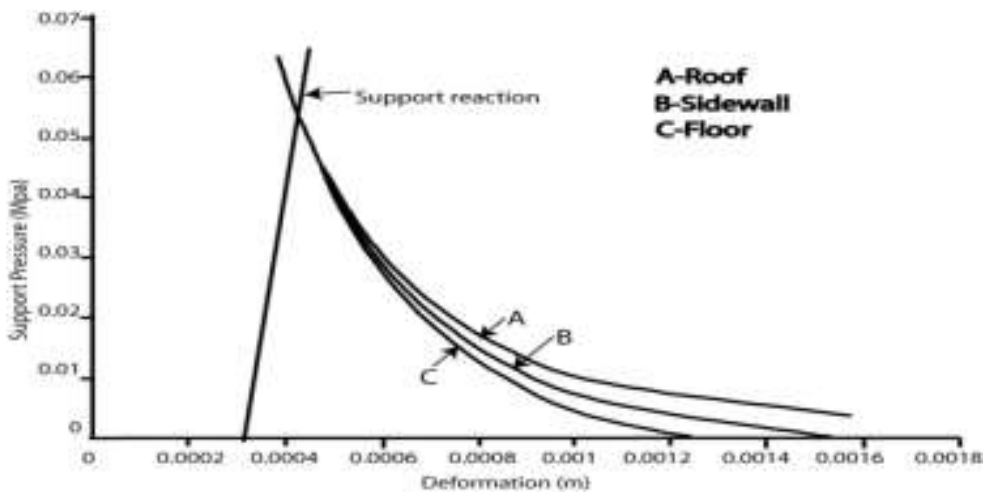

Figure 4(b): Load deformation curve and support reaction of $4.6 \mathrm{~m}$ opening in first category of rock.

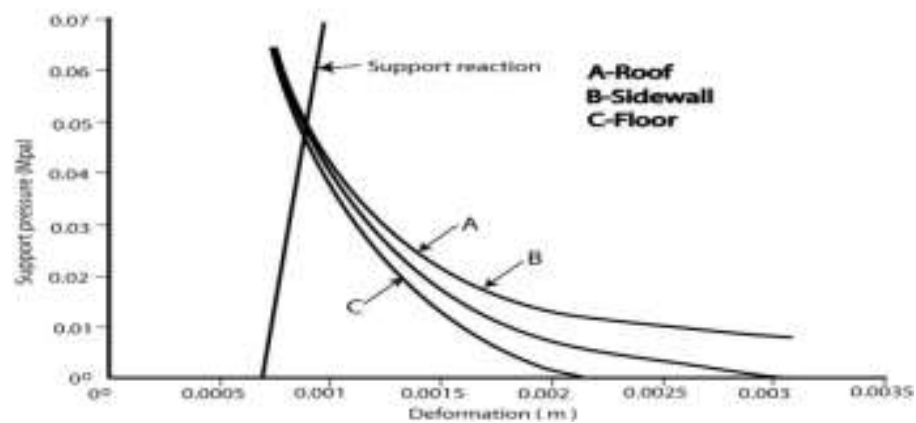

Figure 4(C): Load deformation curve and support reaction of $9.2 \mathrm{~m}$ opening in first category of rock.

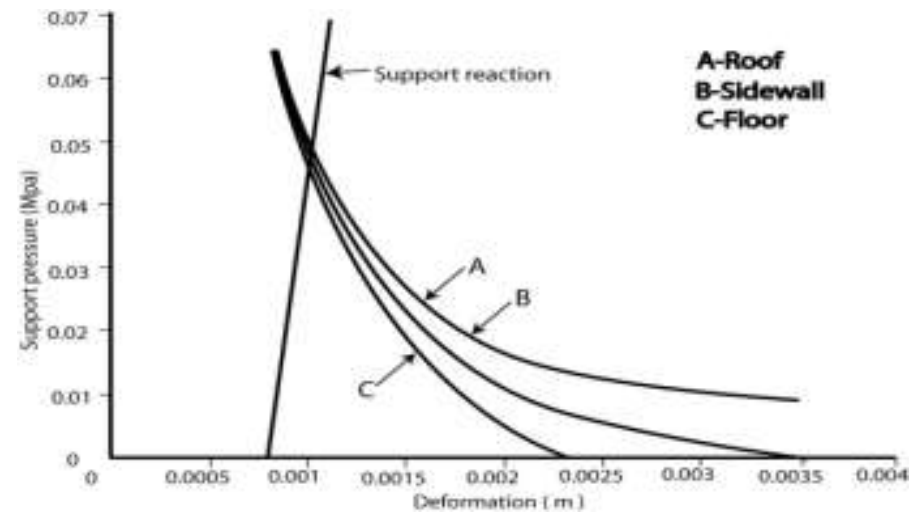

Figure 4(D): Load deformation curve and support reaction of $10.7 \mathrm{~m}$ opening in first category of rock.

\section{$2^{\text {nd }}$ Category of Rock and Support System}

Support pressure and load deformation curves have been driven by using the program (Appendix-A) By using these values load deformation curves for roof, sidewall and floor of different types of openings have been generated (figure: $4 \mathrm{a}, \mathrm{b}, \mathrm{c} \& \mathrm{~d}$ ). The graphs show that, the load deformation curves of sidewall and floor are not increasing. It indicates that there are no needs of support, but the load deformation curves of the roof are increasing from their minimum value. It indicates that support is necessary for roof of the openings. The support for sidewall has also been considered for better stability of the tunnel. In case of floor, the openings Support has not been considered because it has no impact on stability of the openings. Support stiffness and support pressure have been calculated by using the support equations of Hoek and Brown, 1982.

By using the data in the equations of support of Hoek and Brown, 1982, the support pressure and support stiffness values have been driven. The support suitable for particular opening has been

Determined by varying the thickness of lining and considering the load deformation curves (figure: 4 a, $\mathrm{b}, \mathrm{c} \& \mathrm{~d})$. It is found that the shotcrete linings have enough support pressure and stiffness for all kinds of openings to make all of them stable, resisting from further deformation. The support for particular openings is given in Table: 8, behind the point where the load deformation curves begin to increase from their minimum tunnel deformation. 
Optimum Support Design for Openings Considering Intact Rockmass in Production Level of

\begin{tabular}{|l|l|l|l|l|l|}
\hline Opening (m) & $\begin{array}{l}\text { Circular } \\
\text { equivalence }\end{array}$ & $\begin{array}{l}\text { For Roof } \\
\text { Thickness of } \\
\text { lining(m) }\end{array}$ & $\begin{array}{l}\text { Support pressure } \\
\text { (Mpa) }\end{array}$ & $\begin{array}{l}\text { For sidewall } \\
\text { Thickness of } \\
\text { lining(m) }\end{array}$ & $\begin{array}{l}\text { Support } \\
\text { pressure } \\
(\mathbf{M p a})\end{array}$ \\
\hline 2.30 & 1.39 & 0.003 & 0.0743801 & 0.0021 & 0.0496096 \\
\hline 4.60 & 2.70 & 0.008 & 0.1020708 & 0.0041 & 0.0510733 \\
\hline 9.2 & 5.29 & 0.023 & 0.1496939 & 0.013 & 0.0756874 \\
\hline 10.73 & 6.03 & 0.027 & 0.1541318 & 0.015 & 0.0976874 \\
\hline
\end{tabular}

Table: 8. Support for second category of rock

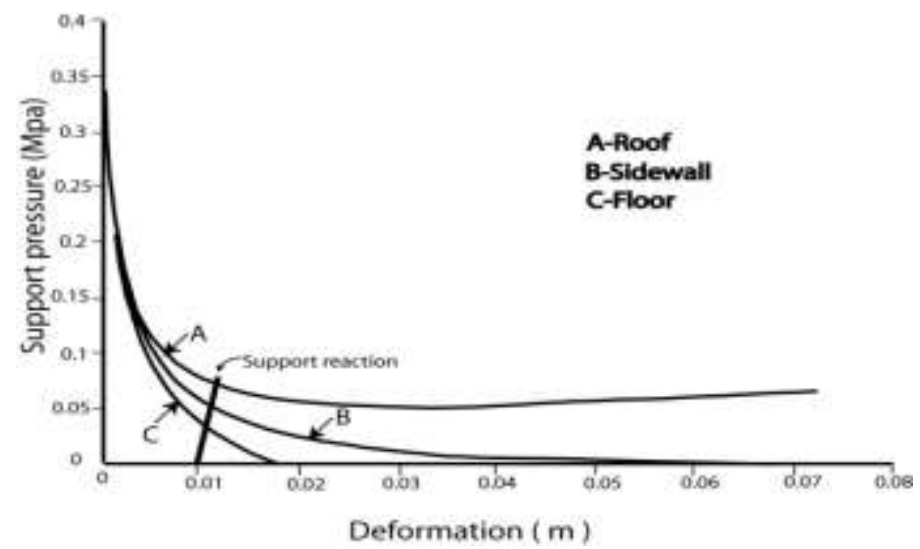

Figure: 5(a), Load deformation curve and support reaction of $2.3 \mathrm{~m}$ opening in second category of rock.

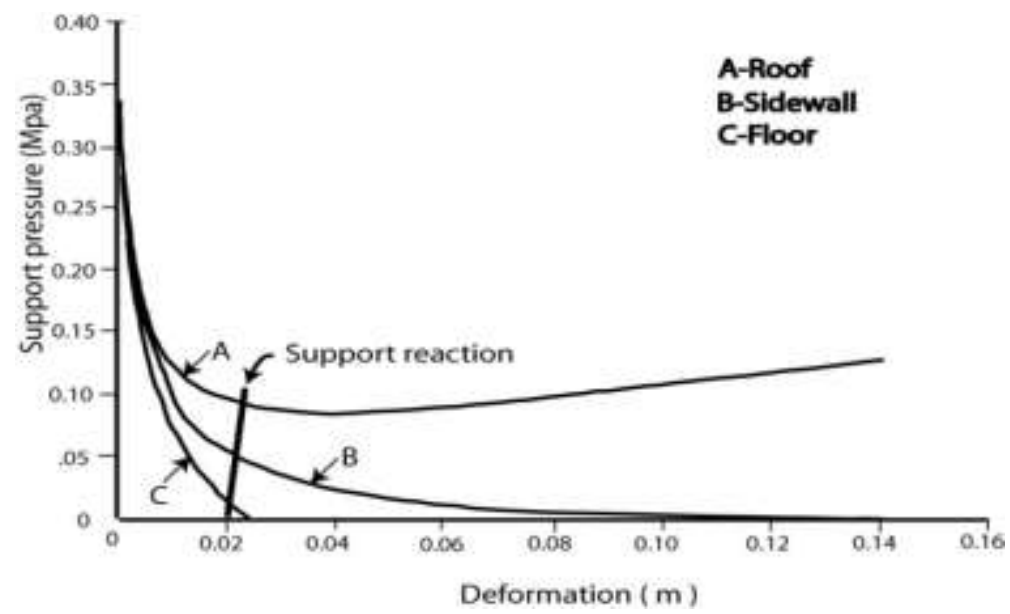

Figure: 5(b), Load deformation curve and support reaction of 4.6m opening in second category of rock.

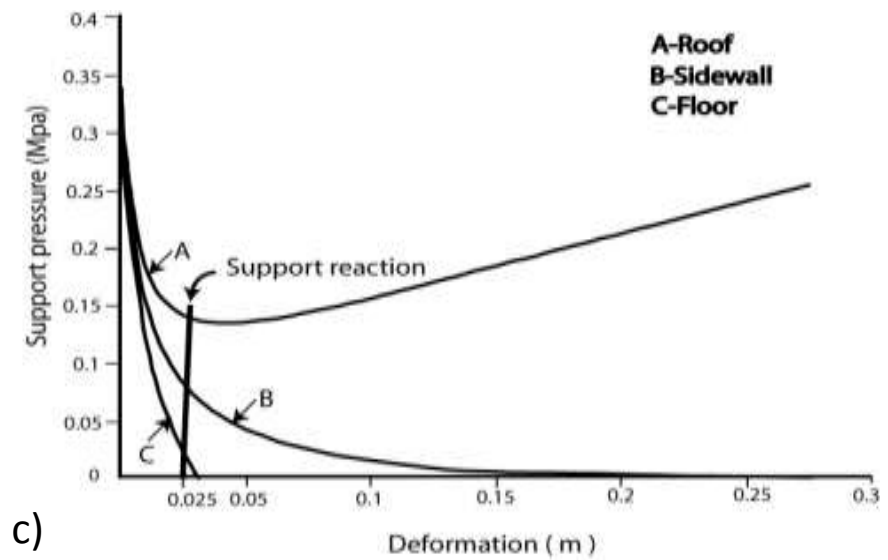

Figure: 5(C), Load deformation curve and support reaction of 9.2m opening in second category of rock. 


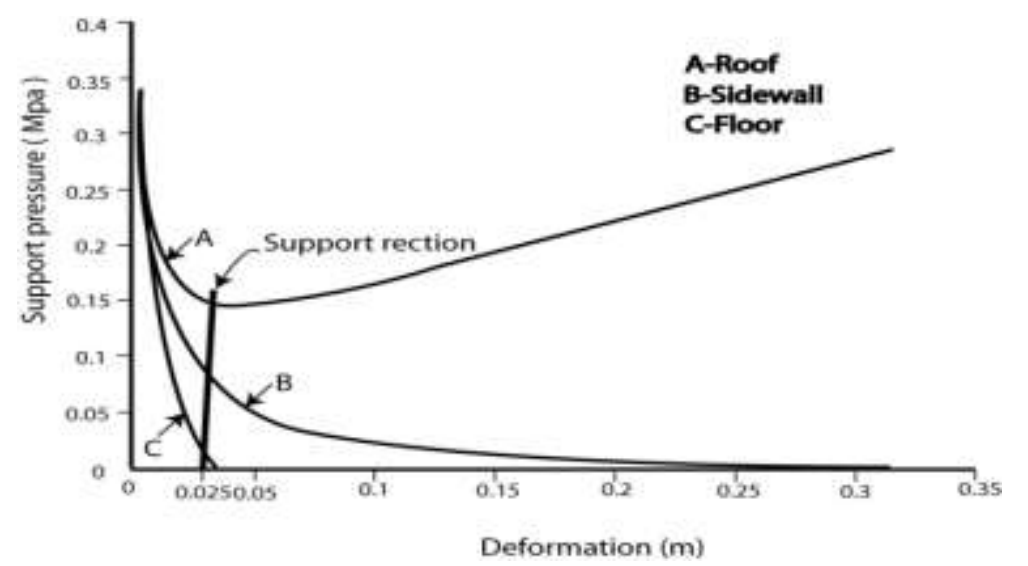

d)

Figure: 5(d), Load deformation curve and support reaction of $10.73 \mathrm{~m}$ opening in second category of rock.

\section{$3^{\text {rd }}$ Category of Rock and Support System}

Tunnel deformation and support pressure values of different types of openings have been derived by using the program of Rock Support Interaction (Appendix-A). From these values the load deformation curves of roof, sidewall and floor of the openings have been generated (figure: 5a, b, c \&d), from these graph it appears that the load deformation curves of floor and sidewall are not increasing. There is no necessity of support installation. The load deformation curves of the roof are increasing steeply from there minimum value. It indicates the necessity of high amount of support installation to make the openings stable. Supports have been considered for sidewall for better stability of the openings. Supports have not been considered for floor because it will not affects the stability of the openings. In order to have effective support for roof shotcrete and rock bolt supports have been considered together as high amount of support needed over there, for sidewall shotcrete support has been considered for sidewall of the openings as less amount of support is needed.

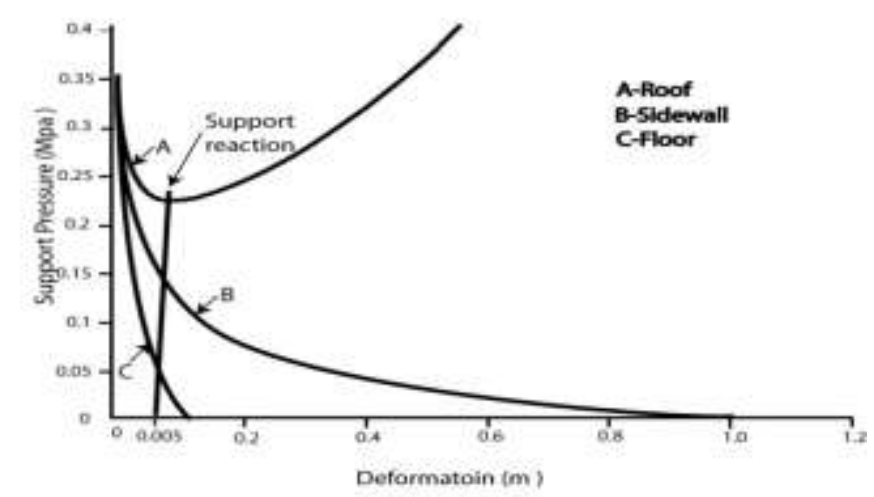

Figure 6(a): Load deformation curve and support reaction of $2.3 \mathrm{~m}$ opening in Third category of rock.

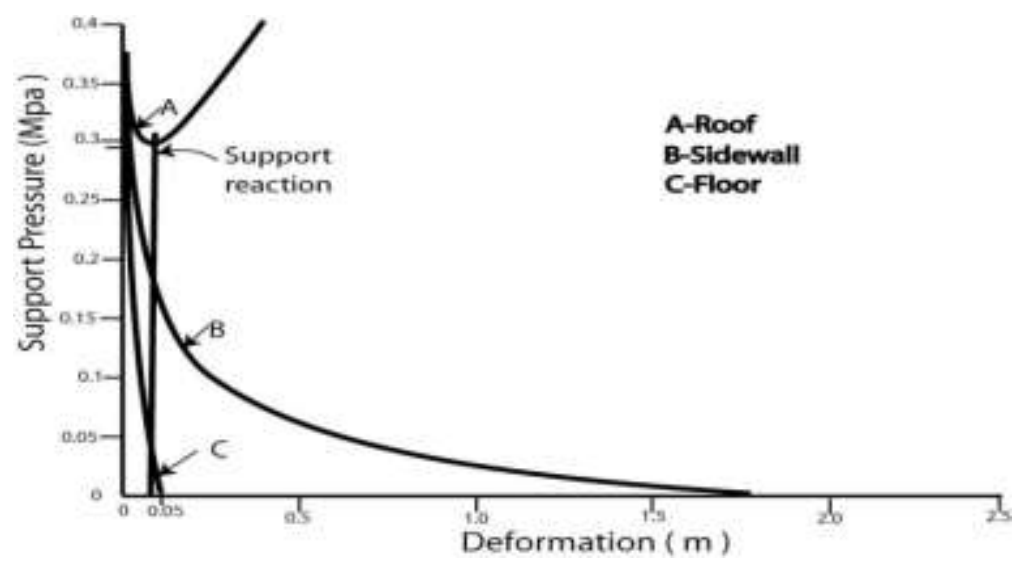

Figure 6(b): Load deformation curve and support reaction of $4.6 \mathrm{~m}$ opening in Third category of rock. 


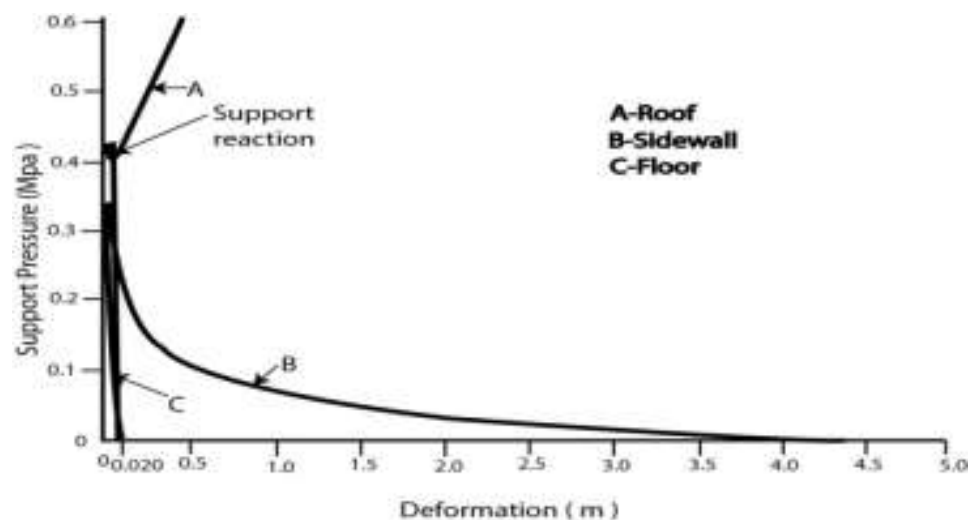

Figure 6(c): Load deformation curve and support reaction of 10.73m opening in Third category of rock.

The support reaction curves have been generated by using the data in the equations of supports (Hoek and Brown, 1982 and following the combined support calculations of Hoek and Brown 1982 (section 2.2). The supports have been estimated for particular openings by considering the load deformation curves and support reactions (figure: $6 \mathrm{a}, \mathrm{b} \& \mathrm{c}$ ). The support system suitable for different types of openings in third category of rock is given in Table: 9.

\begin{tabular}{|c|c|c|c|c|c|c|c|}
\hline \multirow[b]{2}{*}{ Openings } & \multirow[b]{2}{*}{$\begin{array}{l}\text { Circular } \\
\text { equivalence }\end{array}$} & \multicolumn{4}{|l|}{ Roof } & \multicolumn{2}{|c|}{ Sidewall } \\
\hline & & $\begin{array}{l}\text { Shot } \\
\text { crete } \\
\text { lining } \\
\text { (m) }\end{array}$ & $\begin{array}{l}\text { Circulfarence } \\
\text { bolt spacing }\end{array}$ & $\begin{array}{l}\text { Longitudinal } \\
\text { bolt spacing }\end{array}$ & $\begin{array}{l}\text { Support } \\
\text { pressure } \\
\text { (Mpa) }\end{array}$ & $\begin{array}{l}\text { Shot } \\
\text { crete } \\
\text { lining } \\
(\mathrm{m})\end{array}$ & $\begin{array}{l}\text { Support } \\
\text { pressure } \\
\text { (Mpa) }\end{array}$ \\
\hline 2.30 & 1.39 & 0.0075 & 1.35 & 1.35 & 0.2241753 & 0.0060 & 0.148599 \\
\hline 4.60 & 2.70 & 0.025 & 1.0 & 1.0 & 0.2865526 & 0.015 & 0.191613 \\
\hline 10.73 & 6.03 & 0.026 & 0.95 & 0.95 & 0.4531680 & 0.045 & 0.256502 \\
\hline
\end{tabular}

Table: 9, Support requirements for third category of rock

\section{CONCLUSION}

In case of $1^{\text {st }}$ category of rock mass, there has to be considered negligible amount of support or even it can be ignored. In case of $2^{\text {nd }}$ category of rock mass for $2.3,4.6,9.2$ and $10.73 \mathrm{~m}$ openings it has to be considered $0.003,0.008,0.023$ and $0.027 \mathrm{~m}$ shotcrete lining in roof and $0.0021,0.004,0.013$ and $0.015 \mathrm{~m}$ shotcrete lining in sidewall respectively. Finally for $3^{\text {rd }}$ category of rock mass has to be handle very carefully and special care has to be considered for the 2.3, 4.6, 9.2 and 10.73m openings needs to be $0.0095,0.015$, $0.026 \mathrm{~m}$ shotcrete lining with $3 \mathrm{~m}$ long bolt has to be rock bolted with a spacing of $1.15,1.0,0.95 \mathrm{~m}$ respectively in roof and for sidewall $0.006,0.015$ and $0.045 \mathrm{~m}$ shotcrete linings respectively.

\section{Reports:}

[1] Rahman, A., (1987) Geology of Maddhapara area, Dinajpur district, Bangladesh. Rec. Geo. Surv. Bangladesh, V.5,n.2P.1-61

[2] Kores South-South Cooperation Corporeation (KSSCC), (1995) Design projrect report on Development of Maddhapara Granite Mine in Bangladesh. (Unpublished Report of MHMC, P.112)

[3] Kores South-South Cooperation Corporeation (KSSCC), (1998) Design report on Development of Maddhapara Granite Mine in Bangladesh. (Unpublished Report of MHMC, P.112)

Books:

[4] Hoek E. and Brown E.T., (1982) Underground Excavation in Rock, $3^{\text {rd }}$ edition, The Institute of Mining and Metallurgy, London, P.520.

\section{Theses:}

[5] Malek, M.A., (2003) Modification for stope design considering UCS-SF in Maddhapara Granite Mine; an approach of safety measurement (Unpublished M.Sc. thesis report, University of Rajshahi, Bangladesh).

\section{Theses report:}

[6] Badrul Alam A.K.M., (2006) Optimum Support Design for Loopdrift in Maddhapara Granite Mine, Bangladesh (Unpublished M.Sc. thesis report, University of Rajshahi, Bangladesh).

\section{APPENDIX}

Rock Support Interaction Analysis Program \{followed the sequence of calculations of Rock Support Interaction Analysis (Heok and Brown, 1982)\}.

WATFOR-77 V3.0 Copyright WATCOM Systems Inc. 1984,1988 05/12/26 20:24:47 
REAL B,PO,QC,SI,A,C,U,E,P1,M,V,D,N,PR,PF,A1,I,R,EAV,K,UI,PS PRINT*,'ENTER YOUR VALUE FOR M. C. OF INTACT ROCK, B' $\operatorname{READ}(*, *) \mathrm{B}$

PRINT*',ENTER YOUR VALUE FOR M. C. OF INTACT ROCK, SI'

$\operatorname{READ}(*, *) \mathrm{SI}$

PRINT*',ENTER YOUR VALUE FOR INSITUE STRESS MAGNI.,PO'

$\operatorname{READ}(*, *) \mathrm{PO}$

PRINT*,'ENTER YOUR VALUE FOR UNIAXIAL COM. STRE. QC'

$\operatorname{READ}(*, *) \mathrm{QC}$

PRINT*',ENTER YOUE VALUE FOR M. C. OF BROKEN ROCK.MR. ,A'

$\operatorname{READ}(*, *) \mathrm{A}$

PRINT*,'ENTER YOUR YOUR VALUE FOR M. C. OF BROKEN ROCK .SR. ,C'

$\operatorname{READ}(*, *) \mathrm{C}$

PRINT*',ENTER YOUR VALUE FOR POISSON RATIO,U'

$\operatorname{READ}(*, *) \mathrm{U}$

PRINT*',ENTER YOUR VALUE FOR MODULUS OF ELASTICITY,E'

$\operatorname{READ}(*, *) \mathrm{E}$

PRINT*','ENTER YOUR VALUE OF SUPPORT,MPA,P1'

$\operatorname{READ}(* *) \mathrm{P} 1$

$\mathrm{M}=((0.5 *(((\mathrm{~B} / 4) * * 2)+((\mathrm{B} * \mathrm{PO}) / \mathrm{QC})+\mathrm{SI}) * * 0.5))-(\mathrm{B} / 8)$

$\operatorname{WRITE}(* *) \mathrm{M}$

$\mathrm{V}=(\mathrm{PO}-(\mathrm{M} * \mathrm{QC}))$

$\mathrm{D}=((-\mathrm{B}) /(\mathrm{B}+(4 *((((\mathrm{~B} * \mathrm{~V}) / \mathrm{QC})+\mathrm{SI}) * * 0.5))))$

WRITE $(*, *) \mathrm{D}$

$\mathrm{N}=2 *(((\mathrm{~V} /(\mathrm{A} * \mathrm{QC}))+(\mathrm{C} /((\mathrm{A}) * * 2))) * * 0.5)$

$\operatorname{WRITE}(*, *) \mathrm{N}$

IF(P1 .GE. V)THEN

$\mathrm{K}=(((1+\mathrm{U}) / \mathrm{E}) *(\mathrm{PO}-\mathrm{P} 1))$

PRINT*,'THE VALUE OE Ui/ri'

$\operatorname{WRITE}(*, *) \mathrm{K}$

ELSE

$\mathrm{UR}=(((1+\mathrm{U}) / \mathrm{E}) *(\mathrm{M} * \mathrm{QC}))$

PRINT*,'PLASTIC FAILURE

$\mathrm{I}=\mathrm{EXP}(\mathrm{N}-(2 *((\mathrm{P} 1 /(\mathrm{A} * \mathrm{QC}))+(\mathrm{C} /(\mathrm{A}) * * 2)) * * 0.5))$

PRINT*,'THE VALUE OF re/ri'

WRITE $(*, *) I$

$\mathrm{RE}=\mathrm{I} * 2.47$

IF(I .GE. 1.73)THEN

$\mathrm{R}=1.1$ *D

ELSE IF(I .LE. 1.73)THEN

$\mathrm{R}=(2 * \mathrm{D} *(\operatorname{ALOG}(\mathrm{I})))$

END IF

$\mathrm{EAV}=(2 * \mathrm{UR} *(\mathrm{I} * * 2)) /(((\mathrm{I} * * 2)-1) *(1+(1 / \mathrm{R})))$

PRINT*',THE VALUE OF eav'

WRITE $(*, *)$ EAV

$\mathrm{A}=((2 * \mathrm{UR})-\mathrm{EAV}) *(\mathrm{I} * * 2)$

PRINT*,'THE VALUE OF A'

$\operatorname{WRITE}(*, *)$

$\mathrm{K}=1-(((1-\mathrm{EAV}) /(1+\mathrm{A})) * * 0.5)$

END IF

$\mathrm{UI}=\mathrm{K} * 2.47$

PRINT*'DEFORMATION OR DISPLACEMENT,M'

WRITE $(*, *)$ UI

$\mathrm{PR}=(\mathrm{P} 1+(0.03 *(\mathrm{RE}-2.47))) / \mathrm{PO}$

PRINT*',P1 FOR THE ROOF WALL, MPA'

WRITE $(*, *) P R$

$\mathrm{PF}=(\mathrm{P} 1-(0.03 *(\mathrm{RE}-2.47))) / \mathrm{PO}$

PRINT*',P1 FOR THE FLOOR WALL,MPA'

WRITE $(* *) P F$

$\mathrm{PS}=\mathrm{P} 1 / \mathrm{PO}$

PRINT*,'P1 FOR THE SIDE WALLS OF TUNNEL,MPA'

WRITE $(* *) P S$

STOP

END 